\title{
sciendo
}

\section{Motivators and its impacts on job satisfaction in FDI companies - A case study of Eurowindow Vietnam}

\author{
Ho Thanh TRI \\ FaME, Tomas Bata University in Zlin, Czech Republic based at Industrial University of Ho Chi \\ Minh City, Vietnam. \\ hothanhtri@gmail.com
}

Nguyen NGOC-TAN

FaME, Tomas Bata University in Zlin, Czech Republic based at Hanoi University, Vietnam

ngoctanhanu@gmail.com

\author{
Aleš GREGAR \\ FaME, Tomas Bata University in Zlin, Czech Republic \\ gregar@utb.cz \\ Drahomira PAVELKOVA \\ FaME, Tomas Bata University in Zlin, Czech Republic \\ pavelkova@utb.cz
}

\begin{abstract}
This study investigates the factors motivating workers and their levels of job satisfaction at Eurowindow Vietnam - an FDI company in the furniture industry based in Hochiminh City, Vietnam. Data for this study were collected by a surveying 202 office workers of the company. A Likert-scale response format questionnaire was used to identify employment attitudes and job satisfaction. The research was carried out based on the theoretical aspects of job satisfaction. Cronbach's alpha and exploratory factor analysis (EFA) were deployed to test the unidimensionality, reliability, and validity of measurement scales. Correlation analysis was carried out to estimate the relation between dependent and independent variables, and within the independent ones. Moreover, multiple regression analysis was adopted to test the hypotheses of the study. The level of job satisfaction was measured by seven dimensions, namely payment, promotion, supervisor, co-workers, work itself, benefits and work environment. The research results showed that work itself, promotion, payment, and supervisor have significant influences on job satisfaction. Findings of this study provide necessary knowledge for the leadership of Eurowindow Vietnam in boosting job satisfaction of their staff. Other FDI enterprises with the same development level may find these results applicable for their organizations. Recommendations for future research are also presented at the end of the study.
\end{abstract}

Keywords: Motivators, job satisfaction, labor turnover, FDI company, Eurowindow Vietnam

Please cite the article as follows: Tri, H.T., Ngoc-Tan, N., Gregar, A., Pavelkova, D. (2020), "Motivators and its impacts on job satisfaction in FDI companies - A case study of Eurowindow Vietnam", Management \& Marketing. Challenges for the Knowledge Society, Vol. 15, No 1, pp 109-124. DOI: 10.2478/mmcks-2020-0007. 


\section{Introduction}

During the past decade, employee turnover has represented a challenge for almost all organizations. Therefore, all enterprises considered managing employee retention, keeping employee turnover rate below target and industry norms to be the most challenging issue to face. The existence of competent, committed and qualified employees is essential to any company seeking long-term success and sustainable growth. Even if economic times change, employee turnover will remain a fundamental issue for most job groups (Kwon and Rupp, 2013).

Foreign direct investment (FDI) contributes significantly to the economic growth, through the addition of some domestic sources of capital, technology transfer, modern techniques, etc., of the country receiving the investment (Asiedu, 2002; Mina, 2007; Ang, 2008; Tintin, 2013). On the one hand, FDI supplements sources of capital for the economy and increases factors of production such as labor, raw material inputs, etc. which provides employment opportunities for a large part of the population. On the other hand, FDI helps recipient countries to build a business system with foreign capital; diversifies the economic components and; promotes competitiveness among industrial sectors in producing products with higher quality at lower prices. FDI has played an essential role in the economic development of many developing countries.

According to Golejewska (2011), an employee chooses to work in FDI companies instead of local companies due to three motivations, i.e. higher wages, job stability and, skills enhancement. A large number of empirical studies stated that FDI companies pay higher wages than domestic firms in similar activities in developing countries. According to Hijzen et at. (2013), the wage difference between foreign-owned firms and domestic firms ranges from 10 to 70 percent. From the employee's perspective, employment in an FDI company may be more beneficial than the job in a local firm. Filer et al. (1994) indicated that FDI companies in the Czech Republic spent 4.6 times more for hiring and training than domestic firms. This perspective is also reinforced by the researches of the World Bank (1997) and UNCTAD (2005). Moreover, an employee tends to choose stable jobs. Empirical evidence from the United States and Indonesia showed that FDI companies are less likely to shut down than local firms (Bernard \& Jensen, 2007; Harrison \& Scorse, 2010).

Apart from the advantages, Golejewska (2011) also pointed out the drawbacks that make the turnover rate high in FDI companies. They tend to suppress unions to reduce wages, benefits, and labor standards. Besides, working conditions are harsh, atrocious and detrimental to employee's health in sub-contracted factories. The high rate of employee turnover badly affects the bottom-line revenue of the company. Job hopping can be explained by many reasons, including but not limited to, better employment opportunities, unhappiness with the position, culture, or the work environment itself. According to Valaei et al. (2016), losses caused by employee turnover include hiring costs, overtime costs, the morale of the remaining employees, and low productivity.

Therefore, finding empirical evidence to increase employee's satisfaction towards their employment as well as their long-term commitment is of primary importance for the viability and success of the company.

The Vietnamese construction industry has lately enjoyed strong growth, and FDI enterprises in the real estate sector have contributed in large part. As the government of Vietnam pursues the resolution to upgrade its infrastructure and to create a liberal business 
environment for foreign investors, demand for construction materials has skyrocketed, fostering the growth of many construction materials companies, such as Eurowindow, in Vietnam.

Eurowindow (European Plastics Window Company Ltd.) was established on 29th August 2002 under the Vietnamese Law on Foreign Investment. In May 2007, its legal form was officially changed into-to a joint stock company in compliance with the new Investment Law. As a leading glass supplier in Vietnam, Eurowindow's factories are equipped with modern automated production lines imported from leading suppliers based in Germany, Italy, Finland, and Spain. So far Eurowindow has nearly 4,000 staff members, including qualified experts, engineers, and high skill trained workers, with a nationwide distribution network including three branches, approximately 40 showrooms, hundreds of agents and distributors. Therefore, Eurowindow considers human resource as a sustainable competitive advantage. High employee turnover rate has always been a major problem. In big and dynamic areas with lots of job opportunities like Ho Chi Minh City, retaining employees is becoming challenging more than ever.

Table 1. Overview of turnover rate in Eurowindow Company 2013 - 2017

\begin{tabular}{|l|l|l|l|l|l|}
\hline Year & 2013 & 2014 & 2015 & 2016 & 2017 \\
\hline Turnover rate & $18 \%$ & $24 \%$ & $27 \%$ & $29 \%$ & $32 \%$ \\
\hline
\end{tabular}

Source: Human Resource Department of Eurowindow Company

This study, therefore, desires to provide empirical evidence on specific factors that help boost laborer's job satisfaction by choosing a case study of Eurowindow Vietnam - an FDI enterprise based in Hochiminh City in Vietnam. The study adopts quantitative and explanatory approaches through a survey questionnaire as the main inquiry instrument. Measurement scales are taken from well-known scholars in the fields; and unidimensionality, reliability, validity, and correlation are tested before conducting the multiple regression model to test the hypotheses. Results of the study will help confirm the multiple conjectures about motivating factors that impact job satisfaction. In the future, the leadership of enterprises of the same type will have better insight in enhancing their capacity to retain their staff and to secure their long-term commitments.

What do workers want? What are their needs? Are they satisfied with their current jobs, current salaries, and commissions? Is there a relationship between employee satisfaction and employee retention? Under these circumstances, it is necessary to understand the impact of the worker's salary, promotion opportunity, motivation, working environment, good relationship with boss/peers on employee satisfaction before implementing solutions. This study which attempts to identify factors affecting employee satisfaction in Eurowindow, can also be considered as a lesson for FDI companies not only in Vietnam, but also in similar economies.

\section{Theoretical background and hypothesis development}

So far, a wide variety of studies on job satisfaction and employee needs has been conducted. In this literature review, factors affecting job satisfaction will be described. Later in this chapter, a model of job satisfaction will be recommended for this specific study which provides a basis for the development of hypotheses. Before discussing the foundation of job satisfaction, related theories should be observed within the theoretical frame of the research, 
including Maslow's Hierarchy of need theory (Maslow, 1943), the two-factor theory (Herzberg et al., 1959), McClelland's learned needs theory (1987).

\section{The theory of job satisfaction}

Maslow's Hierarchy of need theory is one of the most well-known theories about motivation and satisfaction. Maslow (1943) stated that all individuals have a basic set of needs that must be satisfied over the course of a lifetime. Maslow's hierarchy of needs suggested that individuals have five basic sets of requirements: physiological, safety, love, esteem needs, and self- actualization needs.

On the other hand, Herzberg's two factor theory (Herzberg et al., 1959) is based on two different factors that influence behavior: (1) The first factor influencing job dissatisfaction includes organization policies, working environment and the satisfaction with supervision; (2) The second factor is related to motivating on job satisfaction such as recognition, promotion, achievement, and the intrinsic nature of the work.

Another theory related to this field that should be mentioned is the McClelland's need for achievement (McClelland, 1987). McClelland recommended three basic needs that should be operative in the workplace, namely: (1) The need for achievement, which is an individual's desire for significant accomplishment; for excelling and; be outstanding; (2) The need for power, which is the need to make others behave in a way in which otherwise they would not have acted, to control others, to be influential; (3) The need for connection, which is the need for warm and close interpersonal relationships, to be liked and accepted.

The above-mentioned outstanding theories help to define the conceptual framework and guide this study.

\section{Job satisfaction and antecedent factors}

Numerous research articles in the current literature have presented factors that affect employee turnover intention in organizations. In addition, they have explored the effects of organizational justice on work-related variables such as turnover intention (Campion, 1991; Blau, 1993; McLean et al., 1996; Van Zyl, 1998; Roodt et al., 2002), organizational behavior (Boshoff, 2001; Taba, 2018), and job satisfaction (Graham, 1982; McLean et al., 1996; Roodt et al., 2002; Schulz \& Steyn, 2003; Schmidt, 2007; Valaei et al., 2016). The authors of this study aim to measure empirically the impacts of motivating factors on job satisfaction in FDI companies; and Eurowindow Vietnam - an FDI company based in Hochiminh City, Vietnam, was chosen as a case study.

There are many different interpretations and definitions of job satisfaction. Graham (1982) defined job satisfaction as "the measurement of one's total feelings and attitudes towards one's job." Job satisfaction, in fact, is an employee's feeling about various aspect of the job. According to Schmidt (2007), the causes of job satisfaction relate to status, supervision, co-worker relationships, job content, payment and extrinsic rewards, promotion and physical conditions of the work environment, as well as organizational structure. Similarly, McLean et al. (1996) pointed out that job satisfaction refers to the individual's' feelings toward their job. The author also explained that a diversity of job dimensions including the quality of the employee-supervisor relationship, the physical work environment, the work fulfillment, could influence job satisfaction. Job satisfaction (JS) is connected to the overall satisfaction, namely whether the employee considers retiring or changing jobs. According to Van Zyl (1998), employees can experience a feeling of safety in

Vol. 15, No. 1, Spring, pp. 109-124, ISSN 2069-8887| Management \& Marketing. Challenges for the Knowledge Society 
their work. On the contrary, Roodt et al. (2002) interpreted job satisfaction as individual's positive mental state about their job. They added that individuals with high job satisfaction would display a positive attitude towards their job, and vice versa. Meanwhile, Schulz and Steyn (2003) defined job satisfaction as a group of workers' attitudes concerning work itself, relations at work, cooperation in the workplace, personal characteristics, honors recognition, and incentives.

Smith (1969) introduced a measurement in other to assess five facets: payment, promotions, supervision, co-workers and the work itself. This measurement consists of seventy-two (72) items: nine (9) items each for the facet of promotion and payment, and eighteen (18) items each for work, supervision, and co-workers. However, Smith's measuring instrument has defects. Some researchers have modified it to fit specific contexts. Valaei et al. (2016) combined two components of benefits and working environment to the Adjusted Job Descriptive Index (AJDI) for their research in Information and Communications Technology-Small and Medium-sized Enterprise (ICT-SME). They proposed ten factors as necessary for job satisfaction, namely payment, promotion, fringe benefits, co-worker, supervision, communication, contingent rewards, operating procedures, nature of work, employee's work experience.

Employee satisfaction is perhaps the oldest and most established of all non-financial indicators. All companies should strive to strengthen and grow employee engagement, so it is critical for the mission of the companies to understand how engaged their employees are. The authors of the study have adopted the approach of Valaei et al. (2016) to develop the measuring dimensions of the motivators. To ensure the validity of the predictor variables, a pilot study was conducted to see if the measuring dimensions truly reflect the motivating factors of job satisfaction in an FDI company.

Firstly, 10 experts of Eurowindow were invited to participate in this pilot study. One of them is the representative of the company leadership, 6 of them are from different departments, the remaining 3 are from the Human Resource Department since it is directly responsible for the company's human resource and deemed to have expertise in maintaining the employee satisfaction. They were asked to reorder the 10 dimensions as stated by Valaei et al. (2016) according to their importance and they went through a quick interview of 10 minutes in which they briefly explained their choices.

The results of the pilot study revealed that among the 10 dimensions suggested by Valaei et al. (2016), 3 dimensions, including contingent rewards, operating procedures, and employee's work experience, are the least important and received inadequate attention from the respondents. Consequently, they were removed from the study; only 7 out of 10 motivating factors were retained to serve as predictor variables of the research as described below.

Payment: Arnolds and Boshoff (2001) found that monetary rewards have a significant motivation for top managers. According to McLean et al. (1996), payment (also referred to as wage or salary or remuneration) always appears as a strong dissatisfier and most people perceive they are underpaid. Wan et al. (2014) also agreed with this finding and revealed that educators feel that they do not receive fair salaries for the work they do. Similarly, Taba (2018) founded that senior managers in the public sector were concerned with their remuneration, stated that they need a lot of motivation to commit to the job. Based on the arguments, the authors of this study propose the following hypothesis:

Hypothesis 1: There is a positive impact of payment on job satisfaction.

Vol. 15, No.1,Spring, pp. 109-124, ISSN 2069-8887| Management \& Marketing. Challenges for the Knowledge Society 
Promotion: According to Lemons and Jones (2001), promotion, otherwise known as advancement, is a motivator. His research indicated that this factor contributes significantly to the dissatisfaction of employees. Roodt et al. (2002) asserted that promotions create opportunities for personal growth, increase responsibility and social status. Kosteas (2011) proved that job satisfaction might help to bring promotion opportunities, especially in the case of top managers. It also has a positive effect on employee performance. Therefore, the authors of this study propose the following hypothesis:

Hypothesis 2: There is a positive impact of promotion on job satisfaction.

Supervisor: Boshoff and Mels (1995) defined a supervisor as "a front-line manager who is responsible for the supervision of employees." They also demonstrated that a positive relationship exists between job satisfaction and supervision. A supervisor plays an essential role in providing support, technical guidance and passion for work-related tasks. Alessandri et al. (2017) supported this view by adding that supervisory behavior has a tremendous influence on the development of trust in relationships with employees. Authors of this study hypothesized that:

Hypothesis 3: There is a positive impact of the supervisor on job satisfaction.

Co-workers: Williams and Anderson (1991) stated that job satisfaction increases when having friendly and supportive colleagues. Yeoh (2007) investigated more than 21.000 women and pointed out that those who were lacking support from co-workers tended to suffer from job dissatisfaction. Much empirical evidence suggested that relationships with colleagues have consistently yielded considerable effects on job satisfaction of federal government workers in the United States Clark et al. (2009). An essential characteristic of the relationship between coworkers is cohesiveness as it relates to the group's productivity Roodt et al. (2002). From the positions presented, authors of the study assume that:

Hypothesis 4: There is a positive impact of the co-worker on job satisfaction.

Work itself: Oosthuizen (2001) indicated that "Work itself refers to the doing of the work and the type of work. The job can be repetitive or changing, creative or monotonous, easy or difficult". Employees feel motivated and satisfied if jobs include skill variety, task significance, task identity, autonomy, and feedback Pearson (1991). The nature of the job is a significant source of satisfaction for senior managers, especially for those whose jobs provide challenges and direct feedback (Knoop, 1995; Yalabik et al., 2017). Oosthuizen (2001) agreed that the types of work individuals do contributes to their satisfaction. Thus, the authors of the study propose that:

Hypothesis 5: There is a positive impact of work itself on job satisfaction.

Benefits: Employees' benefits are defined as rewards (medical insurance, working accident insurance, etc.) that they receive for being members of the organization or their positions in the organization. Artz (2010) pointed out that fringe benefits are significant and positive determinants of job satisfaction. According to Lam et al. (2001) rewards (including benefits) have a positive relationship with job satisfaction. He also emphasized that job satisfaction is an essential factor to predict. Based on the above-mentioned arguments, the authors of this study presume that:

Hypothesis 6: There is a positive impact of benefits on job satisfaction.

Work environment: (Pearson, (1991) and; Inamizu, (2016) identified that organizational values and physical conditions are factors related to the work environment. The physical working conditions refer to "the quantity of work and availability of resources such as machines and tools, ventilation, lighting, workspace and air conditioning"

Vol. 15, No. 1, Spring, pp. 109-124, ISSN 2069-8887| Management \& Marketing. Challenges for the Knowledge Society 
Oosthuizen (2001). Lam's research showed that work environment emerged as an influential factor in predicting overall job satisfaction for Chinese restaurant managers. Hence, the authors of this study, hypothesize that:

Hypothesis 7: There is a positive impact of work environment on job satisfaction.

\section{Methodology}

\section{Sample and data collection}

Pilot survey: The survey was conducted from March 2018 to June 2018. A 34 scale-item questionnaire was originally created in English, then carefully translated into Vietnamese. A pilot survey of 15 samples for each version (English and Vietnamese) of the questionnaire was conducted before being delivered to the targeted respondents. Comments and feedbacks from the pilot survey helped to improve the readability, clarity, and comprehensiveness of the questionnaire. Besides, bias is also avoided in the final version. Respondents of this research are full-time office clerks including employees, managers, head and deputy head of the department and leadership at Eurowindow Vietnam based in Hochiminh City, Vietnam. The personal survey question available at https://docs.google.com/forms/d/e/1FAIpQLSf_tLUj646aSGtXHgzTH0aC9Jjh4fhNOA5RHu Z2LTch8P1Itg/viewform?usp=sf_link

Sample size: The sampling method of this study was the convenience sampling method. 220 out of 250 samples delivered were returned, making the response rate up to $88 \%$. After filtering them, some of the questionnaires were removed due to missing values. The final data were based on 202 valid sample questionnaires.

Sample characteristics: As mentioned above, at first the data were collected from 220 questionnaires, after filtering, only 202 of them were valid and were retained to proceed with the analysis. Table 2 summarizes the main characteristics of the samples participating in this study.

Table 2: Sample characteristics ( $\mathrm{N}=202)$

\begin{tabular}{|l|l|c|c|}
\hline \multirow{2}{*}{ Profile } & \multicolumn{1}{|c|}{ Characteristics } & Frequency & (\%) \\
\hline Gender & Male & 121 & 59.9 \\
\cline { 2 - 4 } & Female & 81 & 40.1 \\
\hline & Under 25 & 29 & 14.4 \\
\hline & From 25 to 34 & 160 & 79.2 \\
\hline & From 35 to 44 & 10 & 5.0 \\
\hline Education level & From 45 to 54 & 3 & 1.5 \\
\hline & High schools & 3 & 1.5 \\
\hline & Vocational training & 20 & 9.9 \\
\hline & College & 44 & 21.8 \\
\hline & Bachelor & 133 & 65.8 \\
\hline Time-serving & Master upwards & 2 & 1.0 \\
\hline & Up to 1 year & 49 & 24.3 \\
\hline & From 1 to under 3 years & 89 & 44.1 \\
\hline & From 3 to under 5 years & 45 & 22.3 \\
\hline Working position & From 5 to under 10 years & 19 & 9.4 \\
\hline & Employee & 183 & 90.6 \\
\hline & Manager/Lead & 10 & 5.0 \\
\hline
\end{tabular}

Source: Authors' own research. 


\section{Statistical method}

This study used The Statistical Package for the Social Sciences (SPSS) version 20 for research purpose. The analysis process is implemented as follow:

Step 1: Testing the reliability of the scale: Cronbach alpha is the most common approach to test reliability. According to Hair, Black et al. (1998), Cronbach alpha will be high if the scale is highly correlated. The coefficient of Cronbach Alpha is at least 0.6 and (Corrected Item-Total Correlation) > 0.3 Hair, Black et al. (1998).

Step 2: Applying the EFA to test the convergence of variables in the model. According to Conway and Huffcutt (2003), EFA with principal component, eigenvalue $>=1$ and varimax rotation is used for 7 items under investigation. Hair, Black et al. (1998) also indicated that items with low factor loading $<0.40$ will be eliminated. Then, the reliability analysis was applied to each set of items to assess and refine the measurement item. Items having low Cronbach alpha $<=0.60$ and total correlation coefficient $<=0.3$ were eliminated.

Step 3: Correlation analysis and multicollinearity are carried out to estimate the general relationship between independent variables with dependent variables and the general relationship among independent variables.

Step 4: The linear regression analysis will be used to test the intensity of the impact of the independent variables on the dependent variable.

\section{Measures}

Independent measures: Motivations for job satisfaction are measured according to the 7 aforementioned dimensions, namely Payment (with 4 scale items adopted from Valaei et al. (2016)); Promotion (with 5 scale items, 4 are adopted from Kosteas (2011), and 1 is adopted from Valaei et al. (2016)); Supervisor (with 6 scale items totally adopted from Alessandri, G., et al. (2017)); Co-worker (with 3 scale items totally adopted from Clark et al. (2009)); Work itself (with 5 scale items adopted from Yalabik et al. (2017)); Benefits (with 4 scale items totally adopted from Valaei et al. (2016)); and Work environment (with 4 scale items totally adopted from Valaei et al. (2016)).

Dependent Variables: The authors adopted 3 scale items from Valaei et al. (2016) to measure the dimensions of Job satisfaction.

All the measures were based on the five-point Likert scales (1-strongly disagree, 5strongly agree) (see Table 2).

\section{Empirical results and discussion}

\section{Assessment of measurement scale}

The process of evaluation and refinement of the measurement scale consists of two steps. In the first step, EFA and Cronbach alpha were used to assess unidimensionality and reliability. The second step was conducted using the EFA analysis with all scales together in other to estimate convergent and discriminant validity. In this process, the items which were not able to meet evaluating criteria were removed. For testing the reliability of scale items of all independent constructs, Cronbach's Alpha was used again. Reliability and Validity test results are shown in Table 2 .

Table 2: Indicators: Cronbach's Alpha test results and definitions

\begin{tabular}{|l|l|l|c|}
\hline $\begin{array}{l}\text { Construct } \\
\text { /Items }\end{array}$ & Item & Description & $\begin{array}{c}\text { Corrected } \\
\text { item-total } \\
\text { correlation }\end{array}$ \\
\hline
\end{tabular}

Vol. 15, No. 1,Spring, pp. 109-124, ISSN 2069-8887| Management \& Marketing. Challenges for the Knowledge Society 


\begin{tabular}{|c|c|c|c|}
\hline \multirow{4}{*}{$\begin{array}{l}\text { Pay (Alpha } \\
0.888)\end{array}$} & Pay1 & Get a high salary & 0.709 \\
\hline & Pay2 & The employees are paid by their performance & 0.785 \\
\hline & Pay3 & Salary system is fair & 0.802 \\
\hline & Pay4 & The employee is satisfied with the salary system & 0.727 \\
\hline \multirow{5}{*}{$\begin{array}{l}\text { Promotion } \\
\text { (Alpha = } \\
0.914 \text { ) }\end{array}$} & Pro1 & The employee understands the requirement to get a promotion. & 0.721 \\
\hline & Pro2 & $\begin{array}{l}\text { The company provides the employee with more opportunities to } \\
\text { develop }\end{array}$ & 0.859 \\
\hline & Pro3 & $\begin{array}{l}\text { The company provides the employee with personal development } \\
\text { opportunities }\end{array}$ & 0.774 \\
\hline & Pro4 & The promotion system/policy of the company is good & 0.784 \\
\hline & Pro5 & $\begin{array}{l}\text { The employee is satisfied with promotion opportunities at the } \\
\text { company }\end{array}$ & 0.769 \\
\hline \multirow{6}{*}{$\begin{array}{l}\text { Supervisor } \\
\text { (Alpha = } \\
0.855 \text { ) }\end{array}$} & Sup1 & The superior is a good role-model & 0.707 \\
\hline & Sup2 & $\begin{array}{l}\text { The superior encourages employees' involvement in important } \\
\text { decision making }\end{array}$ & 0.544 \\
\hline & Sup3 & The supervisor makes employees believe in corporate management & 0.717 \\
\hline & Sup4 & The superior makes employees feel respected & 0.637 \\
\hline & Sup5 & Employees are treated fairly & 0.692 \\
\hline & Sup6 & The superior monitors employees effectively & 0.572 \\
\hline \multirow{3}{*}{$\begin{array}{l}\text { Co-worker } \\
\text { (Alpha = } \\
0.837 \text { ) }\end{array}$} & Cow1 & The colleagues are friendly & 0.648 \\
\hline & Cow2 & The employees are doing their job in harmony and with teamwork & 0.723 \\
\hline & Cow3 & The colleagues are willing to support each other & 0.732 \\
\hline \multirow{5}{*}{$\begin{array}{l}\text { Work itself } \\
\text { (Alpha }= \\
0.781 \text { ) }\end{array}$} & Work1 & $\begin{array}{l}\text { The employees can promote their capacity and potential at the } \\
\text { company }\end{array}$ & 0.519 \\
\hline & Work2 & The employee enjoys the current job & 0.509 \\
\hline & Work3 & The job is challenging & 0.666 \\
\hline & Work4 & The job is multitasking & 0.560 \\
\hline & Work5 & The job needs great efficiency & 0.533 \\
\hline \multirow{4}{*}{$\begin{array}{l}\text { Benefits } \\
\text { (Alpha = } \\
0.736 \text { ) }\end{array}$} & Ben1 & The company offers the employee great benefits & 0.629 \\
\hline & Ben2 & The company offers employee health insurance policies & 0.527 \\
\hline & Ben3 & The company supports employees in trouble & 0.536 \\
\hline & Ben4 & The employee is satisfied with the salary of the company & 0.439 \\
\hline \multirow{4}{*}{$\begin{array}{l}\text { Working } \\
\text { environment } \\
\text { (Alpha = } \\
0.564 \text { ) }\end{array}$} & Env1 & The employee does not work under too much pressure & 0.402 \\
\hline & Env2 & The job does not require frequent overtime performance & 0.398 \\
\hline & Env3 & The equipment is safe and clean at the company & 0.285 \\
\hline & Env4 & The job is stable, and the employee feels secure & 0.312 \\
\hline \multirow{3}{*}{$\begin{array}{l}\text { Job } \\
\text { satisfaction } \\
(0.845)\end{array}$} & Js1 & The employees feel satisfied with their performance & 0.701 \\
\hline & Js2 & The employees have long-term plans with their company & 0.686 \\
\hline & Js3 & Generally, employees feel interested in their current job. & 0.751 \\
\hline
\end{tabular}

Source: Authors' own research.

After conducting the EFA, only 6 factors out of the 7 independent constructs, consisting in 27 items were retained which altogether explain $67.885 \%$ of the total variance and the initial eigenvalues of $=1.047$. Scale items of Working environment factor (Env) did not load satisfactorily. For all the 27 items, factor loading ranges from 0.559 to 0.846 and it is higher than 0.40. In this rotation method, the Varimax with Kaiser Normalization was used to provide better reliability. 1 item of the Benefit component (ben4) was moved to the Payment component. The result of Bartlett's Test and KMO indicated that the degree of intercorrelation among the items was suitable for the EFA procedure (KMO =0.903; Chi-square $=3154.682, \mathrm{df}=351$, Sig $=.000)$.

Unidimensionality and reliability of the 6 factors were once again tested and the results are summarized in the following table. 
Table 3: Summary results of testing scales

\begin{tabular}{|c|c|c|c|c|}
\hline Factors & Items & Cronbach's Alpha & $\begin{array}{c}\% \text { of } \\
\text { Variance } \\
\end{array}$ & Assessment \\
\hline Promotion (PRO) & 5 & 0.914 & \multirow{6}{*}{67.885} & \multirow{6}{*}{ satisfied } \\
\hline Payment (PAY) & 5 & 0.888 & & \\
\hline Supervisor (SUP) & 6 & 0.855 & & \\
\hline Work itself (WORK) & 5 & 0.781 & & \\
\hline Co-worker (COW) & 3 & 0.837 & & \\
\hline Benefit (BEN) & 3 & 0.736 & & \\
\hline Job satisfaction (JS) & 3 & 0.845 & 76.443 & satisfied \\
\hline
\end{tabular}

\section{Correlation analysis}

Before conducting a linear regression analysis, the researchers considered the correlation between the independent and dependent variables, estimating the general relationship between independent variables with dependent variables and the general relationship within independent variables in order to see whether the correlations between two independent factors were less than 0.8 Hulland (1999). As suggested by Allison (1999), this study checked the multicollinearity of each independent variable through a variance inflation factor (VIF). According to Allison (1999), VIF index $=1$ means not correlated, from 1 to $5=$ moderately correlated, more than $5=$ highly correlated.

Table 4: Correlation matrix

\begin{tabular}{|c|c|c|c|r|r|r|r|l|}
\hline \multicolumn{2}{|c|}{} & \multicolumn{1}{c|}{ JS } & \multicolumn{1}{c|}{ PRO } & \multicolumn{1}{c|}{ PAY } & \multicolumn{1}{c|}{ SUP } & WORK & COW & BEN \\
\hline \multirow{4}{*}{$\begin{array}{c}\text { Pearson } \\
\text { Correlation }\end{array}$} & JS & 1.000 & & & & & & \\
\cline { 2 - 11 } & PRO & 0.536 & 1.000 & & & & & \\
\cline { 2 - 11 } & PAY & 0.555 & 0.547 & 1.000 & & & & \\
\cline { 2 - 11 } & WORK & 0.567 & 0.659 & 0.570 & 1.000 & & & \\
\cline { 2 - 11 } & COW & 0.479 & 0.410 & 0.329 & 0.355 & 1.000 & & \\
\cline { 2 - 10 } & BEN & 0.414 & 0.267 & 0.377 & 0.507 & 0.181 & 1.000 & \\
\hline
\end{tabular}

Notes: JS = Job satisfaction; PRO = Promotion; PAY = Payment; SUP = Supervisor; WORK = Work itself; $\mathrm{COW}=$ Co-worker; $\mathrm{BEN}=$ Benefit.

Source: Authors' own research.

Table 4 presented the correlation matrix between variables, and, according to the results, all pairs of variables met the criteria set out by Hulland (1999). At the same time, the VIF index (table 5) confirmed that there is no multicollinearity phenomenon between variables in the model.

\section{Regression analysis}

Multiple regression analysis was used to test the hypotheses of the study. The results of the regression analysis are displayed in the following tables.

As it can be seen in Table 5, the results showed that $\mathrm{R}$ square is $=0.480, \mathrm{~F}$ value is 30.042 , sig. $=0.000$. These proved that the linear multiple regressions between independent variables and Job satisfaction are relevant as data and can be used. The Sig value of factors 
showed that four elements among six factors had a significant impact on Job satisfaction. Through the value of $\mathrm{R}$ square, the critical level of the model was $48 \%$, meaning that the six independent variables can explain $48 \%$ of Job satisfaction.

Table 5: Multiple Regression results

\begin{tabular}{|c|c|c|c|c|c|}
\hline \multicolumn{6}{|c|}{ Dependent Variable: Job satisfaction } \\
\hline Variable & Coefficient & Std.Error & t-statistic & p-value & VIF \\
\hline (Constant) & .210 & .293 & .717 & .474 & \\
\hline Promotion & .143 & .071 & 2.003 & .047 & 2.065 \\
\hline Pay & .222 & .061 & 3.662 & .000 & 1.785 \\
\hline Supervisor & .227 & .094 & 2.431 & .016 & 2.417 \\
\hline Work itself & .289 & .066 & 4.383 & .000 & 1.282 \\
\hline Co-worker & .102 & .063 & 1.628 & .105 & 1.439 \\
\hline Benefit & -.023 & .064 & -.366 & .715 & 1.646 \\
\hline Adjusted R- Square & \multicolumn{5}{|c|}{.464} \\
\hline R Square & \multicolumn{5}{|c|}{.480} \\
\hline Durbin-Watson & \multicolumn{5}{|c|}{1.944} \\
\hline $\mathrm{F}(\mathrm{ANOVA})$ & \multicolumn{5}{|c|}{30.042} \\
\hline P-value (ANOVA & \multicolumn{5}{|c|}{.000} \\
\hline
\end{tabular}

Source: Authors' own research.

\section{Study results and discussions}

Based on the results of multiple regression analysis as shown in Table 6, the results of the study can be summarized in the Table below:

Table 6: Study results

\begin{tabular}{|c|c|c|c|c|}
\hline Hypotheses & Relationship & $\begin{array}{l}\text { Standardized } \\
\text { coefficient Beta }\end{array}$ & Sig. & $\begin{array}{c}\text { Testing } \\
\text { hypotheses }\end{array}$ \\
\hline $\mathrm{H} 1$ & WORK ------------ $\rightarrow$ JS & 0.256 & 0.000 & supported \\
\hline $\mathrm{H} 2$ & PAY -------------- $\rightarrow$ JS & 0.253 & 0.000 & supported \\
\hline H3 & BEN -------------- $\rightarrow$ JS & -0.024 & 0.715 & rejected \\
\hline $\mathrm{H} 4$ & COW -------------- $\rightarrow$ JS & 0.101 & 0.105 & rejected \\
\hline $\mathrm{H} 5$ & SUP -------------- $\rightarrow$ JS & 0.195 & 0.016 & supported \\
\hline H6 & PRO ------------ $\rightarrow$ JS & 0.149 & 0.047 & supported \\
\hline
\end{tabular}

Notes: JS = Job satisfaction; PRO = Promotion; PAY = Payment; SUP = Supervisor; WORK = Work itself; COW = Co-worker; BEN = Benefit.

Source: Authors' own research.

The results of this study demonstrate that four variables, Work itself, Payment, Supervisor, and Promotion are related to Job satisfaction. However, this study found insufficient evidence to confirm the relationship between Benefit and Co-workers with Job satisfaction. The results of this study suggest that if managers want to ensure high levels of job satisfaction among their employees, they should prioritize it taking into consideration the factors examined in this study and their importance as follows: (1) Work itself, (2) Payment, (3) Supervisor and (4) Promotion. These factors can change a person's perception of the job. As a result, employee performance will be boosted.

Findings of the study reveal that Work itself, and not Payment, is the most important and motivating factor that determines the job satisfaction of the staff at Eurowindow Vietnam. Generally speaking, the staff would prefer to work that to be allowed to improve 
themselves, enhance their own capacity and materialize their sleeping potentials. Besides, work should be reasonably challenging, not repetitive and should make the laborer feeling accomplished. This is in line with what Pearson (1991) said about employees feeling motivated and satisfied if jobs are various in terms of skills required, significant in terms of the importance and autonomous regarding control. Knoop (1995), Yalabik et al. (2017) and Oosthuizen (2001) share the same opinion as stated in the literature on this topic.

Moreover, the results of this study affirm that Payment is the second most important motivator. Leaderships of the companies are suggested to ensure a fair and pay-perperformance remuneration system, and, of course, the remuneration rate must be competitive on the labor market. Compensation or monetary rewards are always a very sensitive factor especially when the laborers usually think that they are underpaid as reflected in McLean et al. (1996) and Taba (2018).

In addition, Supervisor is also a factor that impacts job satisfaction. The findings of this study recommend that the leadership of the company must pay adequate attention to the supervising positions. It is the supervisor who serves as a great source of inspiration. Supervisors are the most visible images of the company leadership representing the management power. They must be a good example and a role model for the employee to follow. They must be fair in treatment and make the employees feel that they are respected, help in growing the employee's pride in the organization and believe in the leadership of the organization. Being of such importance, the supervisor is an influential factor towards job satisfaction as stated by Boshoff and Mels (1995).

The last motivator that demonstrates its influence on job satisfaction in this study is Promotion. The study results show that, in order to have long-term commitments of the employees and make them feel satisfied with the job, good policy or system of promotion must be introduced in the company. The leadership of the company must ensure that employees are aware of the requirements and their promotion opportunities. Employees have a desire to develop themselves through tasks assigned. This is also shared by Roodt et al. (2002) in literature.

\section{Conclusion, limitations, and recommendations Conclusion}

The main aim of this study was to find out the factors affecting job satisfaction among employees, to help businesses reinforce employees' satisfaction and to reduce employees' turnover. The study was conducted based on theories of motivation, theoretical models, hypothesis testing quantitative research approaches. The case study was implemented through data collected from a survey using a tailored questionnaire. Data collected from 202 employees were analyzed in a quantitative manner.

The regression results showed that four variables including Work itself, Payment, Supervisor, and Promotion have positive impacts on Job satisfaction of the employee at Eurowindow. Knoop (1995), Yalabik et al. (2017) and Oosthuizen (2001) share the same opinion as stated in the literature on this topic. The productivity of human resources depends on their satisfaction level and, consequently, satisfied recruits stay with the company for a longer time, while in case of dissatisfaction, productivity will be lower, and employees will be more likely to quit their jobs. Companies are likely to increase their competitive advantage by reducing employees' negative attitude towards their jobs, 
increasing productivity as well as lessening the hidden costs of turnover. This study also contributed to a conceptual model describing the relationship among the components of Job satisfaction.

\section{Limitations and recommendations}

This study aims to empirically examine the seven factors impacting job satisfaction. However, it, reveals certain limitations and open avenues for future studies. The study did not mention the impact of the workers' behavioral response, organizational culture, social factors, work-life balance, economic crisis and market conditions which could influence the predictors of the outcome variable. On another hand, the sample size of this study is quite modest.

There may be underlying reasons behind the failure of finding sufficient evidence proving the positive association between the two factors of Benefits and Co-workers with Job satisfaction. This also leaves rooms for future studies.

Future studies can use this model to formulate new research or increase the generalizability of this study in another industry; especially in FDI companies in developing countries. Time-series data of a longitudinal study would allow researchers to have a better understanding of a causal relationship between motivators and job satisfaction compared with the one-time study. This is highly recommended directions for future studies.

Acknowledgment: The authors would like to thank the Internal Grant Agency of FaME for providing financial support to carry out this research. Funding was extended through TBU No. IGA/FaME/2018/019.

\section{References}

Alessandri, G., Borgogni, L., \& Latham, G. P. (2017). A dynamic model of the longitudinal relationship between job satisfaction and supervisor-rated job performance. Applied Psychology, 66(2), 207-232. https://doi.org/10.1111/apps.12091

Allison, P. D. (1999). Multiple regression: A primer. Pine Forge Press.

Ang, J.B., (2008). Determinants of foreign direct investment in Malaysia. Journal of Policy Modeling, 30(1), 185-189. https://doi.org/10.1016/j.jpolmod.2007.06.014

Artz, B. (2010). Fringe benefits and job satisfaction. International journal of manpower, 31(6), 626-644.

Arnolds, C. A., \& Boshoff, C. (2001). The challenge of motivating top management: A need satisfaction perspective. SA Journal of Industrial Psychology, 27(1), 39-42. DOI 10.4102/sajip.v27i1.773

Asiedu, E., (2002). On the Determinants of Foreign Direct Investment to Developing Countries: Is Africa Different? World Development, 30(1), 107-119. https://doi.org/10.1016/S0305-750X(01)00100-0

Bernard, A. B., \& Jensen, J. B. (2007). Firm structure, multinationals, and manufacturing plant deaths. The Review of Economics and Statistics, 89(2), 193-204.

Blau, G. (1993), "Further exploring the relationship between job search and voluntary individual turnover", Personnel Psychology, 46(2), 313-330.

Boshoff, C., \& Mels, G. (1995). A causal model to evaluate the relationships among supervision, role stress, organizational commitment and internal service quality. 
European Journal of marketing, 29(2), 23-42.

https://doi.org/10.1108/03090569510080932

Campion, M. A. (1991). Meaning and measurement of turnover: Comparison of alternative measures and recommendations for research. Journal of applied psychology, 76(2), 199.

Clark, A. E., Kristensen, N., \& Westergard-Nielsen, N. (2009). Job satisfaction and co-worker wages: Status or signal?. The Economic Journal, 119(536), 430-447. https://doi.org/10.1111/j.1468-0297.2008.02236.x

Conway, J. M., \& Huffcutt, A. I. (2003). A review and evaluation of exploratory factor analysis practices in organizational research. Organizational research methods, 6(2), 147-168. DOI: $10.1177 / 1094428103251541$

Filer, R. K., Schneider, O., \& Svejnar, J. (1994). Wage and Non-Wage Labor Cost in the Czech Republic-The Impact of Fringe Benefits.

Graham, G. H. (1982). Understanding human relations: the individual, organization, and management. Science Research Associates.

Hair, J. F., Jr., R. E. Anderson, R. L. Tatham, and W. C. Black (1998) Multivariate Data Analysis with Readings, 5th Edition. Englewood Cliffs, NJ: Prentice Hall.

Harrison, A., \& Scorse, J. (2010). Multinationals and anti-sweatshop activism. American Economic Review, 100(1), 247-73. DOI:10.1257/aer.100.1.247

Herzberg, F., Mausner, B., \& Snyderman, B. B. (1959). The Motivation to Work, John Wiley \& Sons. Inc., New York, 195.

Hijzen, A., Martins, P. S., Schank, T., \& Upward, R. (2013). Foreign-owned firms around the world: A comparative analysis of wages and employment at the micro-level. European Economic Review, 60, 170-188. https://doi.org/10.1016/j.euroecorev.2013.02.001

Hulland, J. (1999). Use of partial least squares (PLS) in strategic management research: A review of four recent studies. Strategic management journal, 20(2), 195-204. https://doi.org/10.1002/(SICI)1097-0266(199902)20:2<195::AIDSMJ13>3.0.C0;2-7

Inamizu, N. (2016). Spurious correlation between work environment and job satisfaction. Annals of Business administrative science, 15(5), 199-209.

DOI:10.7880/abas.0160803a

Knoop, R. (1995). Relationships among job involvement, job satisfaction, and organizational commitment for nurses. The journal of psychology, 129(6), 643-649.

Kosteas, V. D. (2011). Job satisfaction and promotions. Industrial Relations: A Journal of Economy and Society, 50(1), 174-194. https://doi.org/10.1111/j.1468232X.2010.00630.x

Lam, T., Baum, T., \& Pine, R. (2001). Study of managerial job satisfaction in Hong Kong's Chinese restaurants. International Journal of Contemporary Hospitality Management, 13(1), 35-42. https://doi.org/10.1108/09596110110365634

Kwon, K., \& Rupp, D. E. (2013). High-performer turnover and firm performance: The moderating role of human capital investment and firm reputation. Journal of Organizational Behavior, 34(1), 129-150. https://doi.org/10.1002/job.1804

Lemons, M. A., \& Jones, C. A. (2001). Procedural justice in promotion decisions: using perceptions of fairness to build employee commitment. Journal of Managerial Psychology, 16(4), 268-281. https://doi.org/10.1108/02683940110391517 
Maslow, A. H. (1943). A theory of human motivation. Psychological Review, 50(4), 370. McClelland, D. (1987).Human motivation. Cambridge, UK: Cambridge University Press.

McLean, E. R., Smits, S. J., \& Tanner, J. R. (1996). The importance of salary on job and career attitudes of information systems professionals. Information \& Management, 30(6), 291-299. https://doi.org/10.1016/S0378-7206(96)01059-2

Mina, W., (2007). The location determinants of FDI in the GCC countries. Journal of Multinational Financial Management, 17(4), 336-348. https://doi.org/10.1016/j.mulfin.2007.02.002

Oosthuizen, T. F. J. (2001). Motivation influencing worker performance in a technical division of Telkom SA. Professional Accountant, 1(1), 19-30. https://doi.org/10.4102/ac.v1i1.4

Taba, M. I. (2018). Mediating effect of work performance and organizational commitment in the relationship between the reward system and employees' work satisfaction. Journal of Management Development, 37(1), 65-75. https://doi.org/10.1108/JMD11-2016-0256

Tintin, C., (2013). The determinants of foreign direct investment inflows in the Central and Eastern European Countries: The importance of institutions. Communist and PostCommunist Studies, 46(2), 287-298. https://doi.org/10.1016/j.postcomstud.2013.03.006

Pacesila, M. (2014). The relationship between motivational theories and the current practices of motivating NGO's human resources in Romania. Management Research and Practice, 6(1), 5.

Pearson, R. (1991). The human resource: managing people and work in the 1990's. McGrawHill Book Co Ltd.

Roodt, G., Rieger, H., \& Sempane, M. E. (2002). Job satisfaction in relation to organizational culture. SA Journal of Industrial Psychology, 28(2), 23-30. https://doi.org/10.4102/sajip.v28i2.49

Schmidt, S. W. (2007). The relationship between satisfaction with workplace training and overall job satisfaction. Human Resource Development Quarterly, 18(4), 481-498. DOI: $10.1002 / \mathrm{hrdq} .1216$

Schulz, S., \& Steyn, T. (2003). Educators' motivation: Differences related to gender, age and experience. Acta Academica, 35(3), 138-160.

Smith, P. C. (1969). The measurement of satisfaction in work and retirement: A strategy for the study of attitudes.

Van Zyl, E. S. (1998). Die effek van regstellende aksie op die streservaring van'n groep swart werknemers. SA Journal of Industrial Psychology, 24(1), 22-25. https://doi.org/10.4102/sajip.v24i1.643

Valaei, N., \& Rezaei, S. (2016). Job satisfaction and organizational commitment: An empirical investigation among ICT-SMEs. Management Research Review, 39(12), 1663-1694. https://doi.org/10.1108/MRR-09-2015-0216

UNCTAD. 2005. World Investment Report: Transnational Corporations and the Internalization of R\&D. New York and Geneva: United Nations.

Wan, Y. K. P., Wong, I. A., \& Kong, W. H. (2014). Student career prospect and industry commitment: The roles of industry attitude, perceived social status, and salary expectations. Tourism Management, 40, 1-14. https://doi.org/10.1016/j.tourman.2013.05.004 
Williams, L. J., \& Anderson, S. E. (1991). Job satisfaction and organizational commitment as predictors of organizational citizenship and in-role behaviors. Journal of management, 17(3), 601-617.

World Bank. 1997. Malaysia: Enterprise Training, Technology, and Productivity. Washington, DC: World Bank.

Yalabik, Z. Y., Rayton, B. A., \& Rapti, A. (2017, December). Facets of job satisfaction and work engagement. In Evidence-based HRM: a global forum for empirical scholarship (Vol. 5, No. 3, pp. 248-265). Emerald Publishing Limited. DOI:10.1108/EBHRM-082015-0036

Yeoh, T. E. S. (2007). The Facet Satisfaction Scale: Enhancing the measurement of job satisfaction. University of North Texas. 